Original Article (short paper)

\title{
Which defensive tactical indicators are associated with victory in the semifinals and finals of the 2014 FIFA World Cup?
}

\author{
Leonardo Panice $^{1}$ (D) , Pedro Paulo Deprá ${ }^{1}$ (D) , Matheus de Oliveira Jaime ${ }^{1}$ (D) , Julio Cesar da Costa (i) $^{2}$, \\ Ademar Avelar $^{1}$ (D) , Claudio Kravchychyn ${ }^{1}$ (D) , Sergio Freitas Junior ${ }^{1}$ (D) , Paulo Henrique Borges s $^{1,2}$ (i) \\ ${ }^{1}$ Universidade Estadual de Maringá, Departamento de Educação Física, Maringá, PR, Brasil; \\ ${ }^{2}$ Universidade Estadual de Londrina, Departamento de Educação Física, Londrina, PR, Brasil.
}

\begin{abstract}
Aim: The objective of this study was to verify whether the match winners in the semifinals and finals of the FIFA World Cup 2014 were those who presented the highest frequency of pressing and intense behaviors in the recovery of ball possession. Methods: The sample was composed of 533 defensive tactical sequences performed by the four finalist teams in the 2014 FIFA World Cup. The independent t-test was used to compare tactical indicators between winning and losing teams and the chi-square test $\left(\mathrm{X}^{2}\right)$ was applied to assess the association between the variables. Results: In the first $\left(\mathrm{X}^{2}=48.47 ; P<0.01\right)$ and second halves of regular matches $\left(\mathrm{X}^{2}=64.10 ; P<0.01\right)$, the evaluated teams recovered the ball in the defensive zone. However, during the first and second periods of extra time, the highest frequencies of ball recovery were found in the middle defensive zone $(P$ $<0.01$ ). Conclusion: It is concluded that the semi-finalist and finalist teams from the 2014 FIFA World Cup sought to recover the ball in the defensive zone, and pressing opponent movements when they were losing the matches.
\end{abstract}

Keywords: soccer; athletic performance; notational analysis; observational methodology.

\section{Introduction}

In recent decades, there has been an increase in the number of studies that aim to investigate sports performance during a soccer match. Among the variables that can be studied, the distance covered, type of activity ${ }^{1-3}$, intensity ${ }^{4}$, comparisons between different game positions ${ }^{5,6}$, and efficiency of actions and technical performance during a match ${ }^{7-10}$ have gained prominence in the scientific literature, providing important information to professionals involved in this context.

There is a prevalence of investigations focused mainly on aspects related to the physical dimension of a match, to the detriment of the tactical dimension ${ }^{11}$. The tactical dimension refers to the set of movements carried out in the game space to correctly solve the space-time constraints imposed by the opponents ${ }^{12}$. The movements represent the product of the articulation of different factors intrinsic to a team, such as the coach's game ideas for the phases and moments of the match, the characteristics of the players, the training method, and the cultural context of the club ${ }^{13}$.

When observing investigations related to the tactical dimension in the literature, it can be noted that the majority of studies have concentrated their efforts on the analysis of the offensive phase of the match ${ }^{9,14-18}$. Knowledge related to the defensive phase should not be neglected, as collective effectiveness requires the coordinated implementation of defensive tactical indicators ${ }^{19,20}$.

In this context, a study conducted by Barreira et al. ${ }^{21}$ found that during the 2010 FIFA World Cup, the defensive tactical indicators "interception" and "defensive behavior followed by a pass" were the most prevalent by semifinalists. In addition, elite teams usually react immediately to the loss of ball possession, aiming to recover it quickly ${ }^{22}$, and the increase in the number of fouls raises the probability of winning the match ${ }^{23}$.

Despite recent efforts to investigate the defensive phase of the match, the lack of standardization of variables, combined with the small number of publications on high-performance matches ${ }^{9}$, contribute to a scenario that is still not well elucidated, leaving doubts about defensive tactical indicators that could help teams win their matches. This information may be fundamental to coaches, allowing the reinforcement of defensive actions and strategies during training.

Based on the observation of several authors and soccer coaches regarding tactical indicators that promote better effectiveness in the defensive phase of the match ${ }^{24,25}$, our initial hypothesis was that the winning teams in the finals during the 2014 FIFA World Cup would be those who performed intensely and pressing behavior to recover ball possession, in the most advanced sectors of the field, seeking to bring the different sectors together within the adopted tactical system, through reducing the depth of the opponent's attack.

Thus, this study aimed to verify if the teams that won their matches in semifinals and the finals of the 2014 FIFA World Cup were those that showed the highest frequency of intense and pressing behavior in the search for possession of the ball. 


\section{Methods}

\section{Sample}

The sample was composed of 533 defensive tactical sequences performed by the four finalist teams in the 2014 FIFA World Cup during the following matches: Brazil 1-7 Germany, Netherlands 0-0 Argentina, Brazil 0-3 Netherlands, and Germany 1-0 Argentina. Defensive tactical sequences are understood as any play in which the analyzed team loses possession of the ball and organizes itself to avoid an opposing goal. From these sequences, the following inclusion parameter was applied for the choice of plays; the movie footage enabled topographic visualization of the field and identification of the variables. The following were considered as exclusion parameters: i) plays from dead balls; ii) penalty kicks; and iii) plays that ended with a foul from the attacking team, except the offside rule. The local ethics committee (Proc. $\mathrm{n}^{\circ}{ }^{2}$ 2.797.346) approved the project.

\section{Ad hoc instrument}

The tactical indicators applied in this study were suggested by Castelo ${ }^{25}$. Moreover, owing to the flexibility of the observational methodology of the matches ${ }^{26}$, and in an attempt to increase the ecological validity of the results, we opted for the defensive tactical indicators presented in Frame 1.

To observe the reliability of the variables presented in Frame 1,60 defensive sequences ( $11.25 \%$ of the total) were randomly selected and reassessed by the main researcher 3 weeks after the first analysis. Between the first and second evaluations, the researcher did not analyze the videos. The intra-class correlation coefficient (ICC) was used for quantitative variables and the Kappa index (k) for qualitative variables. The following values were obtained: Ball recovery zone $(\mathrm{k}=1.00)$; defensive pressure $(\mathrm{k}=0.81)$; removing deepness $(\mathrm{k}=0.82)$; defensive time spent ( $\mathrm{ICC}=0.98)$; number of occupied corridors $(\mathrm{k}=$ 0.82 ); number of tackles (ICC $=0.89$ ); number of suffered kicks $(\mathrm{ICC}=0.96)$; and action result $(\mathrm{k}=1.00)$.

Besides test-retest reliability, it was conducted the same reliability evaluation by an independent researcher (inter-observer reliability). The following values were obtained: Ball recovery zone $(\mathrm{k}=1.00)$; defensive pressure $(\mathrm{k}=0.82)$; removing deepness $(\mathrm{k}=0.83)$; defensive time spent (ICC $=$ $0.94)$; number of occupied corridors $(\mathrm{k}=0.81)$; number of tackles (ICC $=0.93)$; number of suffered kicks $(\mathrm{ICC}=0.87)$; and action result $(\mathrm{k}=1.00)$.

\section{Procedures}

The data were collected through videos of the matches provided by open media. To facilitate the topographic visualization of the playing field, the cameras were located in an upper plane of the playing field. The recorded matches refer to the teams. Following the data collection, the videos were evaluated using Match Vision Studio Premium ${ }^{\circledR}$ software, which has been used as a reference in conducting studies with observational methodology $y^{9,10,28-30}$.

\section{Statistical analysis}

The data were analyzed using SPSS 23.0 software. The normality of the data was assessed using the KolmogorovSmirnov test. The independent t-test was used to compare tactical indicators between winning and losing teams. The chisquare test $\left(\mathrm{X}^{2}\right)$ was applied to assess the association between the variables. Data are expressed using absolute frequency (f), percentage (\%), mean, and standard deviation, with their respective units of measurement. The level of significance adopted was $5 \%$.

Frame 1 - Defensive tactical indicators and their conceptual definitions.

Defensive tactical indicators

Ball recovery zone (BRZ)

Defensive pressure (DP)

Removing deepness (RD)

Defensive time spent (DTS)

Number of occupied corridors (NOC)

Number of tackles (NT)

Number of suffered kicks (NSK)

Action result (AR)

\section{Conceptual definition}

Location where the team recovered ball possession, according to the field campogram proposed by Garganta $^{27}$ and Gréhaigne, Mahut, \& Fernande $z^{26}$

Refers to the collective pressure behavior applied to the attackers

Coordinated movements of advancing the last defensive line according to offensive moves

Duration of the defensive phase from the moment of loss of possession to the recovery of the ball

This criterion refers to the number of corridors predominantly occupied during the defensive phase of the match

How many times the team disrespected the rules of the match

Consists of the number of the times the attackers were able to shoot at the goal

Total success (resumption of ball possession) and lack of success (the team conceded the goal or the opposing team could kick at goal)

Source: Adapted from Castelo ${ }^{25}$. 


\section{Results}

Table 1 shows the characterization of the defensive tactical indicators in the analyzed sequences. There was a higher frequency of ball recoveries in the defensive zone for all teams. Germany presented the highest number of recovered balls in the offensive midfield. Regarding the reaction of the defensive block, Germany was the only team that obtained more frequency in the "active" reaction. Furthermore, the Argentiniane team most commonly removed depth from the opponent's attack $(\mathrm{P}=0.01)$.

Table 2 presents the means and standard deviations of the quantitative defensive tactical indicators of the analyzed teams. All teams presented similar numbers.

As demonstrated in Figure 1, the teams recovered the ball predominantly in the defensive zone in both the first $\left(\mathrm{X}^{2}=\right.$ 48.47) and the second halves of the matches $\left(X^{2}=64.10\right)$. In the first and second halves of extra time, to preserve the result or seek victory, there was a higher frequency of recoveries in the middle defensive zone $\left(X^{2}=19.86\right.$ vs. $X^{2}=9.50$, respectively), which represents an advance down the field and an attempt to recover the ball in more advanced regions of the playing field.

Furthermore, inferential statistics showed no significant association $\left(\mathrm{X}^{2}=4.39 ; \mathrm{P}=0.11\right)$ between the result of the confrontation and the ball recovery zone, which points to the similarity in the place where the ball was recovered between winners and losers.

There was a significant association between the variable "removing deepness" and the status of the match $\left(\mathrm{X}^{2}=7.30\right.$; $\mathrm{P}=0.01)$. It was observed that the losers removed more depth from the opposing offensive actions than the winners (221 vs. 203 actions).

Finally, no significant differences were observed between the winning and losing teams in terms of the duration of the defensive phase $(22.25 \mathrm{~s} \pm 12.53 \mathrm{~s}$ vs. $23.73 \mathrm{~s} \pm 12.46 \mathrm{~s} ; \mathrm{t}=-1.36$; $\mathrm{P}=0.17)$, number of occupied corridors $(2.81 \pm 0.38$ vs. 2.78 $\pm 0.41 ; \mathrm{t}=0.94 ; \mathrm{P}=0.34)$, and number of tackles committed $(0.14 \pm 0.37$ vs. $0.13 \pm 0.36 ; \mathrm{t}=0.32 ; \mathrm{P}=0.74)$.

Table 1 - Characterization of the defensive tactical indicators performed by the 2014 FIFA World Cup semifinalist and finalist teams

\begin{tabular}{|c|c|c|c|c|c|}
\hline & Germany $(n=138)$ & Argentina $(n=154)$ & Brazil $(n=104)$ & Netherlands (n=137) & \multirow{2}{*}{$\mathbf{X}^{2}$} \\
\hline & $f(\%)$ & $f(\%)$ & $f(\%)$ & $f(\%)$ & \\
\hline $\mathrm{DZ}$ & $73(52.9)$ & $72(46.8)$ & $53(51.0)$ & $70(51.1)$ & \multirow{3}{*}{11.21} \\
\hline MDZ & $42(30.4)$ & $71(46.1)$ & $40(38.5)$ & $52(38.0)$ & \\
\hline $\mathrm{MOZ}$ & $23(16.7)$ & $11(7.1)$ & $11(10.6)$ & $15(10.9)$ & \\
\hline Active reaction & $71(51.4)$ & $71(46.1)$ & $50(48.1)$ & 68 (49.6) & \multirow[b]{2}{*}{0.89} \\
\hline Passive reaction & 67 (48.6) & $83(53.9)$ & $54(51.9)$ & $69(50.4)$ & \\
\hline $\mathrm{RD}$ & $91(65.9)$ & $132(85.7)$ & $75(72.1)$ & $126(92.0)$ & \multirow[b]{2}{*}{35.83} \\
\hline NRD & $47(34.1)$ & $22(14.3)$ & $29(27.9)$ & $11(8.0)$ & \\
\hline
\end{tabular}

Note: $\mathrm{DZ}=$ Defensive zone; $\mathrm{MDZ}=$ Middle defensive zone; $\mathrm{MOZ}=$ Middle offensive zone; $\mathrm{RD}=$ removed depth; $\mathrm{NRP}=$ did not remove depth.

Table 2 - Characterization of the defensive tactical indicators by mean (standard deviation) performed by the 2014 FIFA World Cup semifinalist and finalist teams

\begin{tabular}{lcccccc}
\hline & $\begin{array}{c}\text { Germany } \\
(\mathbf{n}=\mathbf{1 3 8})\end{array}$ & $\begin{array}{c}\text { Argentina } \\
(\mathbf{n}=\mathbf{1 5 4})\end{array}$ & $\begin{array}{c}\text { Brazil } \\
(\mathbf{n}=\mathbf{1 0 4})\end{array}$ & $\begin{array}{c}\text { Netherlands } \\
(\mathbf{n}=\mathbf{1 3 7})\end{array}$ & $\mathbf{F}$ & $\mathbf{P}$ \\
\hline DTS (s) & $20.86(12.35)$ & $23.84(12.91)$ & $22.48(11.80)$ & $24.53(12.54)$ & 2.33 & 0.07 \\
NOC $\left(\mathrm{n}^{\circ}\right)$ & $2.79(0.40)$ & $2.79(0.41)$ & $2.76(0.44)$ & $2.83(0.36)$ & 0.63 & 0.59 \\
NSK $\left(\mathrm{n}^{\circ}\right)$ & $0.14(0.37)$ & $0.09(0.31)$ & $0.16(0.38)$ & $0.16(0.39)$ & 1.33 & 0.26 \\
\hline
\end{tabular}

Note: DTS = Defensive time spent; NOC = Number of occupied corridors; NSK = number of suffered kicks. 
1st Half

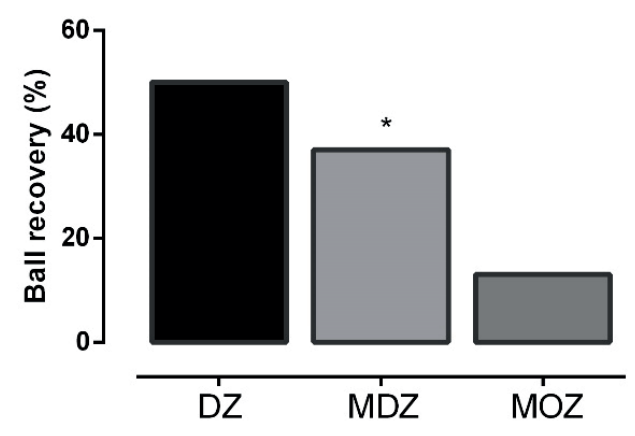

1st Extra Time

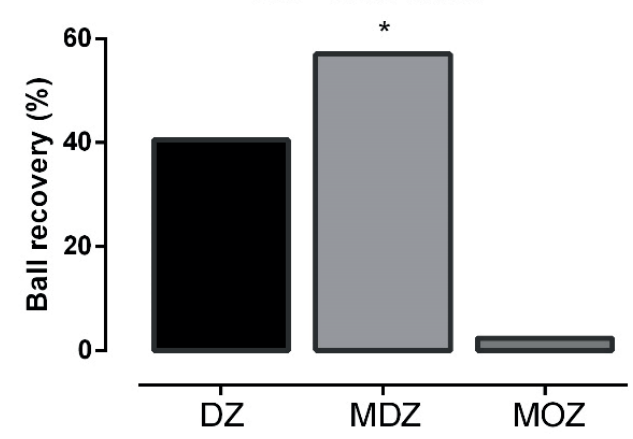

2nd Half

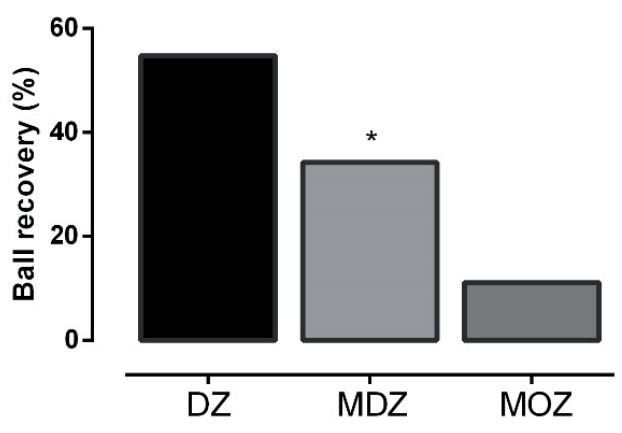

2nd Extra Time

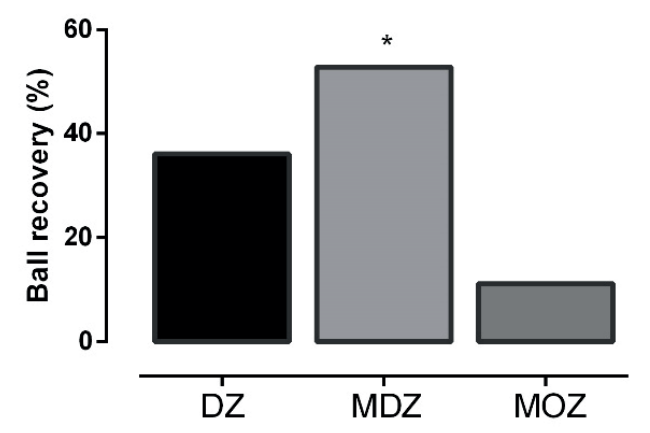

Figure 1 - Comparison of the percentage of the ball recovery between the first and second halves of the analyzed matches. Note: *Significant association $(\mathrm{P}<0.05)$.

\section{Discussion}

The objectives of this study were to verify whether the match winners in the finals of the FIFA World Cup 2014 were those who presented the highest frequency of pressing and intense behaviors in search of ball possession. The main findings partially confirmed the initial hypotheses of the study, pointing out that the intersectoral compaction, expressed by the depth removed from the opponent's attack, was greater in the teams that lost their respective matches. Although the teams that were losing the game sought to retake the ball in advanced zones of the field, the recovery zone was not associated with a positive result of the match. In addition, similar behaviors were observed concerning the duration of the defensive phase, the number of occupied corridors, and the number of tackles between the winners and losers, which possibly indicates other reasons that led the teams to success or failure in the matches.

The team that obtained the highest rates of recovery of the ball in the middle defensive zone was Germany, which could be a factor that led the team to the title of the competition, since failing to regain ball possession can compromise the result ${ }^{22}$. Furthermore, in a study by Volgelbein et al. ${ }^{20}$, it was found that the faster the team retrieves the ball, the greater its success in matches.

The results also suggest that the champion of the competition was the only team that obtained more frequency in the active reaction of the defensive block - although no association was observed (Table 1), which may be another factor for its success in the championship. This was also found in the study by Villela ${ }^{31}$, who analyzed the best teams in the 2010 FIFA World Cup, and the two highest-placed teams demonstrated efficiency in recovering the ball and having a greater number of athletes in the sector where the ball was located. Collectively, this information might explain the German success in the competition, since they recovered the ball predominantly in the defensive midfield with an active reaction, not letting the ball get close to their own goal.

In addition, the defensive indicator "removed depth" proved to be an important parameter in high-level teams (Table 1), since all the analyzed plays showed a higher frequency of this variable. Serrano $^{32}$ points out that to achieve defensive success, it is necessary to recognize the moment when the opponent's offensive depth may be removed. Carvalhal ${ }^{33}$, on the other hand, explains how to recognize the moments for removing depth. For him; the entry of the ball into a determined area of the field recognized as important to put pressure on the opponent, a player receiving the ball backward, a poorly executed pass resulting in a difficult reception to the opponent, or a long and high pass are tactical-technical indicators that the team must use to remove depth.

The duration of the defensive sequences, the number of occupied corridors, and the number of tackles performed by the teams analyzed were similar. As they are elite teams, the four investigated teams may have a similar tactical-strategic pattern for these variables. Thus, we cannot affirm that the duration of the defensive sequence and the number of occupied corridors and 
defensive tackles contributed to victory or defeat. Silva ${ }^{34}$ found similar results in the analysis of the teams of the 2008 Brazilian soccer championship. In the aforementioned study, the faults committed were not considered predictors of a team's success.

In Figure 1, it can be observed that in both the first half $\left(\mathrm{X}^{2}=\right.$ 48.47; $\mathrm{P}<0.01)$ and the second half of the matches $\left(\mathrm{X}^{2}=64.10 ; \mathrm{P}\right.$ $<0.01$ ), teams recovered the ball predominantly in the defensive zone. This result was also found in the studies by Gréhaigne et al. ${ }^{35}$ and Barreira et al. ${ }^{21}$, in which there was a higher incidence of ball recovery in the defensive zone. In the first and second halves of extra time, to preserve the result or seek victory, there was a higher frequency of recoveries in the middle defensive zone $\left(\mathrm{X}^{2}\right.$ $=19.86 ; \mathrm{P}<0.01$ vs. $\mathrm{X}^{2}=9.50 ; \mathrm{P}<0.01$, respectively), which represents an advance down the field and an attempt to recover the ball in more advanced regions of the playing field. Another plausible explanation may be the fatigue of the teams since players were more widely spaced on the field and performed the retake of the ball in different areas of the field.

In addition, inferential statistics did not show a significant association $\left(\mathrm{X}^{2}=4.39 ; \mathrm{P}=0.11\right)$ between the result of the confrontation (victory or defeat) and the recovery zone of the ball, which points to the similarity of the place where players recovered the ball. Silva et al. ${ }^{36}$ pointed out that in small-sided games, the losing teams presented a greater number of defensive actions in the offensive field, while the winning teams recovered the ball in the defensive zone. Due to the inconsistencies in this information, it is believed that the recovery zone of the ball is combined with other tactical-technical-strategic, offensive, and defensive indicators to achieve victory.

A significant association was also found between the withdrawal of depth and the status of the match, with the semifinal teams that lost the matches presenting a higher frequency of this tactical behavior. Possibly, since they were losing the game, the teams tried to advance the lines to quickly recover the ball. The teams that were winning the match played in a lower block. However, in this study the quality of the variable was not analyzed, therefore, the losing teams may have taken more depth than the opponents, but without success, because they left spaces for penetration by the opponent.

A possible limitation of the study was the reduced number of analyzed matches as well as their margin of victory. A further limitation of the study was the unbalanced pattern of results found in those investigated games, especially in Brazil 1-7 Germany, and Brazil 0-3 Netherland, which limits the application of the results and conclusions of the current study for a different sample ${ }^{37}$. Future research should seek to evaluate different teams and leagues to verify how defensive tactical indicators varies in different contexts.

\section{Conclusions}

It is concluded that the teams that lost the games in the semifinals and finals during the 2014 FIFA World Cup removed depth from the attackers. In addition, during the regular playing time, the recovery of the ball occurred more frequently in the defensive zone, whereas in overtime the most frequent zone was the middle defensive zone.

\section{References}

1. Barros CP, Leach S. Technical efficiency in the English Football Association Premier League with a stochastic cost frontier. Appl Econ Lett. 2007;14(10):731-741.

2. Di Salvo V, Baron R, Tschan H, Calderon-Montero FJ, Bachl N, Pigozzi F. Performance characteristics according to playing position in elite soccer. Int J Sports Med. 2007;28(3):222-227.

3. Rampinini E, Bishop D, Marcora SM, Ferrari-Bravo D, Sassi R, Impellizzeri FM. The validity of simple field tests as indicators of match-related physical performance in top-level professional soccer players. Int J Sports Med. 2007;28(3):228-235.

4. Ade J, Fitzpatrick J, Bradley PS. High-intensity efforts in elite soccer matches and associated movement patterns, technical skills, and tactical actions. information for position-specific training drills. J Sports Sci. 2016; 34(24):2205-2214.

5. Rechenchosky L, Borges PH, Menegassi VM, Jaime MO, Guilherme J, Teoldo I, et al. Comparison of tactical principles efficiency among soccer players from different game positions. Hum Mov. 2017;18(5):11-18.

6. Konefał M, Chmura P, Zacharko M, Chimura J, Rokita A, Andrzejewski A. Match outcome vs match status and frequency of selected technical activities of soccer players during UEFA Euro 2016. Int J Perform Anal Sport. 2018;18(4):568-581.

7. Dellal A, Keller D, Carling C, Chaouachi A, Wong P, Chamari K. Physiologic effects of directional changes in intermittent exercise in soccer players. J Strength Cond Res. 2010;24(12):3219-3226.

8. Dellal A, Jannault R, Lopez-Segovia M, Pialoux V. Influence of the numbers of players in the heart rate responses of youth soccer players within 2 vs. 2, 3 vs. 3 and 4 vs. 4 small-sided games. J Hum Kinet. 2011;28(1): 107-114.

9. Borges PH, Garganta J, Oliveira JG, Jaime MO, Menegassi VM, Rechenchosky L, et al. Tactical efficacy and offensive game processes adopted by Italian and Brazilian youth soccer players. Motriz. 2019;25(2):e101922.

10. Jaime MO, Kim I, Menegassi VM, Rechenchosky L, Magossi M, Kravchychyn C, et al. Examining offensive tactical actions performed by youth soccer players with different competitive contexts. J Phys Educ.2020;31(1):e3121.

11. Sarmento H, Marcelino R, Anguera MT, Campaniço J, Matos N, Leitão JC. Match analysis in football: a systematic review. J Sports Sci. 2014;32(20): 1831-1843.

12. Teoldo I, Guilerme J, Garganta J. Para um futebol jogado com ideias: concepção, treinamento e avaliação do desempenho tático de jogadores e equipes. Curitiba, Appris, 2015.

13. Hewitt A, Greenham G, Norton K. Game Style in Soccer: What is it and can we quantify it? Int J Perform Anal Sport. 2016;16(1):355-372.

14. Machado JC, Barreira D, Garganta J. eficácia ofensiva e variabilidade de padrões de jogo em futebol. Rev Bras Educ Fís Esporte. 2013;27(4):667-677.

15. Sarmento H, Figueiredo A, Lago-Peñas C, Milanovic Z, Barbosa $\mathrm{A}$, Tadeu $\mathrm{P}$, et al. Influence of tactical and situational variables on offensive sequences during elite football matches. J Strength Cond Res. 2018;32(8):2331-2339.

16. Sgrò F, Aiello F, Casella A, Lipoma M. The effects of match-playing aspects and situational variables on achieving score-box 
possessions in the Euro 2012 Football Championship. J Hum Sport Exerc. 2017;12(1):58-72.

17. Praça GM, Lima BB, Bredt SG, Sousa RB, Clemente FM, Andrade AG. Influence of match status on players' prominence and teams' network properties during the 2018 FIFA World Cup. Front Psychol. 2019;10(1): 1-8.

18. Clemente FM, Couceiro MS, Martins FM, Figueiredo AJ. Análise de jogo no futebol: métricas de avaliação do comportamento coletivo. Motricidade. 2014;10(1):14-26.

19. Bayer C. O ensino dos desportos colectivos. Lisboa, Dinalivros, 1994.

20. Vogelbein M, Nopp S, Hökelmann A. Defensive transition in soccer - are prompt possession regains a measure of success? A quantitative analysis of German Fußball-Bundesliga 2010/2011. J Sports Sci. 2014;32(11):1076-1083.

21. Barreira D, Garganta J, Machado JC, Anguera MT. Effects of ball recovery on top-level soccer attacking patterns of play. Rev Bras Cineantropom Desempenho Hum. 2014;16(1):36-46.

22. Kempe M, Vogelbein M, Memmert D, Nopp S. Possession vs. Direct Play: evaluating tactical behavior in elite soccer. Int J Sports Sci. 2014;6(4):35-41.

23. Liu H, Gómez MA, Gonçalves B, Sampaio J. Technical performance and match-to-match variation in elite football teams. J Sports Sci. 2015;34(6):509-518.

24. Amieiro N. Defesa à zona no futebol: um pretexto para refletir sobre o jogar bem, ganhando! Lisboa, Visão e Contextos, 2010.

25. Castelo J. Futebol: A Organização do jogo. Lisboa, Edições FMH, 1996.

26. Gréhaigne JF, Mahut B, Fernandez A. Qualitative observation tools to analyze soccer. Int J Perform Anal Sport. 2001;1(1): 52-61.

27. Garganta J. Competências no ensino e treino de jovens futebolistas. Lecturas. 2001; 8(1): 1-15.

28. Camerino O, Castaner M, Anguera M. mixed methods research in the movement sciences: case studies in sport, physical education, and dance. Sport Educ Soc. 2015;20(2):277-282.

29. Silveira LA, Menegassi VM, Rechenchosky L, Oliveira A, Rinaldi W, Borges PH. análise das sequências táticas ofensivas das categorias sub-15 e sub-17 de um clube profissional de futebol brasileiro. Pensar a Prática. 2018;21(4):904-912.

30. Fernandez J, Camerino O, Anguera M, Jonsson G. Identifying and analyzing the construction and effectiveness of offensive plays in basketball by using systematic observation. Behav Res Methods. 2009;41(3):719-730.

31. Villela LS. Eficiência do sistema defensivo das quatro primeiras colocadas da copa do mundo de futebol-2010: quantificação dos atletas presentes nos setores de recuperação da posse de bola. Rev Bras Futsal e Fut. 2011;3(8):159-174.

32. Serrano JCF. Organização e gestão de uma equipa do futebol jovem para o futebol profissional: relatório final de estágio profissionalizante realizado na equipa de juniores A do Grupo Desportivo Estoril Praia na época desportiva 2015/2016. Lisboa. Tese [Doutorado em Educação Física] - Universidade de Lisboa; 2016.

33. Carvalhal C, Lage B, Oliveira JM. Futebol - Um saber sobre o saber fazer. Estoril, PrimeBooks, 2014.

34. Silva DAS. Testes específicos para avaliação no futebol. Lecturas. 2008;13(122): 1-8.

35. Gréhaigne JF, Marchal D, Duprat E. Regaining possession of the ball in the defensive area in soccer. In: Science and Football IV. London, Spinks, 2002, p. 112-120.

36. Silva RNB, Costa IT, Garganta JM, Muller ES, Castelão DP, Santos J. Desempenho tático de jovens jogadores de futebol: comparação entre equipes vencedoras e perdedoras em jogos reduzidos. Rev Bras Cienc Mov. 2013;21(1):75-90.

37. Lupo C, Tessitore A. How Important is the Final Outcome to Interpret Match Analysis Data: The Influence of Scoring a Goal, and Difference Between Close and Balance Games in Elite Soccer: Comment on Lago-Penas and Gomez-Lopez (2014). Percept Mot Skills. 2016;122(1):280-285.

\section{Corresponding author}

Paulo Henrique Borges

Department of Physical Education, State University of Maringá. Colombo Avenue, 5790, Block M06, Room 18. Postal Code: 87020-900, Maringá, Paraná, Brazil. Email: pauloborges.uem@gmail.com

Editor: Dustin Jay Oranchuk. Auckland University of Technology/New Zealand

Manuscript received on May 23, 2020

Manuscript accepted on July 31, 2020

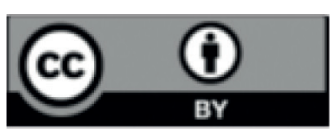

Motriz. The Journal of Physical Education. UNESP. Rio Claro, SP, Brazil - eISSN: 1980-6574 - under a license Creative Commons - Version 4.0 